\title{
Synthesis of a Novel Sensor Electrode Based on Bromothymol Blue as an Indicator Electrode in Potentiometric Acid-Base Titration in Aqueous Solution
}

\author{
Nasser M Abu Ghalwa*, Fawzi kodih, Nader B Farhat and Rewaa J Abu Saelik \\ Chemistry Department, Al-Azhar University, Palestine
}

Submission: January 16, 2020; Published: March 06, 2020

"Corresponding author: Nasser M Abu Ghalwa, Chemistry Department, Al-Azhar University, Gaza, Palestine

\begin{abstract}
A modified bromothymol blue BTB electrode was prepared by spin coating of the BTB indicator on conducting glass substrate, and its use as indicator electrode to potentiometric acid-base titration in aqueous solution at $298 \mathrm{~K}$ was developed. The change of the open circuit potential with $\mathrm{pH}(\mathrm{E}-\mathrm{pH})$ curve is linear with slope of $0.052 \mathrm{~V} / \mathrm{Dec}$ at $298 \mathrm{~K}$. The standard potential of this electrode, E0, was determined with respect to the SCE as reference electrode. The recovery percentage for potentiometric acid-base titration using G/BTB as indicator electrode was calculated Keywords: Potentiometry; Sensor; Conducting Glass; Titration; Indicator Electrode; Bromothymol Blue
\end{abstract}

\section{Experimental}

At the recent years, there has been an expanding interest for chemical analyzers, which are suited for a quick, accurate and in field ion analysis. There is a great interest for easy to use, sensitive, low-cost and maintenance free chemical analyzers for economical real time analysis of environmentally important ions [1]. Titration is a very useful and reliable technique, which is widely used in different fields such as the food industry, scientific research, and chemical, clinical and pharmaceutical laboratories. Potentiometric titration belongs to chemical methods of analysis in which the endpoint of the titration is monitored with an indicator electrode that records the change of the potential as a function of the amount usually the volume of the added titrant of exactly known concentration and the potentiometric titration have a more selective character when acid-base, complexometric or precipitation reactions are explored [2-5].

The Potentiometric sensors based on the potential gap between a working electrode (WE) and a reference electrode (RE), at zero current [1]. This potential is related to the activity of the analyte in the solution, which is considered an effective concentration, in contact with the electrode surface. In potentiometric sensors, a local equilibrium is established at the sensor interface, where either the electrode or membrane potential is measured, and information about the composition of a sample is obtained from the potential [6].

In acid base titration, the unknown concentration of an acid or base is determined by neutralizing the analyte with an acid or base of known concentration. pH indicators are frequently weak acids or bases which is used in titrations in analytical experiments to determine the extent of a chemical reaction. Because of the subjective determination of color, $\mathrm{pH}$ indicators are susceptible to imprecise readings $[7,8]$. Different types of electrode have been used as acid-base indicator electrodes. Of those, the most frequently used are the titanium, hydrogen-palladium and other electrodes [9-12].

Recently, researchers have been interested in studying the composites of conducting electrode film. Composite materials of sensor electrode have superior properties from where broader potential window, higher signal-to-noise ratio, time and Speed of response mechanical stability enabling their application in flowing systems, and resistance toward passivation. the last requirement is especially important because electrode fouling is probably the biggest obstacle to more frequent applications of electroanalytical methods in environmental analysis $[13,14]$. 
Bromothymol blue (also known as bromothymol sulfone phthalein and BTB) is a pH indicator for reactions between strong acids and bases. It is mostly used in applications that require measuring substances that would have a relatively neutral $\mathrm{pH}$ (near 7). A solution of bromothymol exhibits two forms acidic forms (yellow color) and basic form (blue color) [15] (Figure 1).
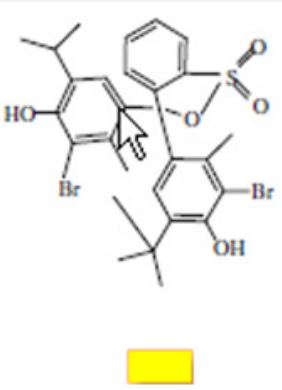
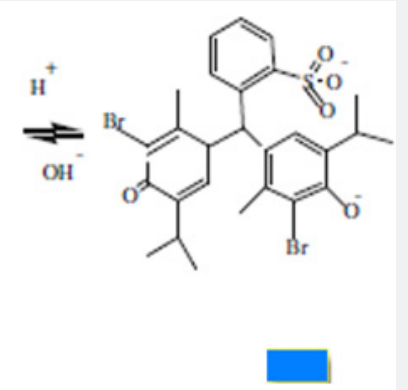

Figure 1: Colors of Bromothymol blue for different forms.

This study focuses on the bromothymol blue indicator BTB to prepare a new modified electrode coated on conducting glass film as sensor (glass / indicator electrode), for used in potentiometric acid base titration.

\section{Experimental}

\section{Chemicals}

The chemicals used in potentiometric titrations and preparation the electrode was tetraethyl orthosilicate (TEOS), bromothymol blue (BTB), hydrochloric acid, ammonia, Acetic acid, phosphoric acid, sodium hydroxide, sulfuric acid, citric acid and disodium phosphate. The chemicals are of analytical pure grade.

\section{Synthesis of Materials}

\section{Preparation of Hydrolyzed TEOS}

A mixture of $2.5 \mathrm{ml}$ of absolute ethanol, $0.86 \mathrm{ml}$ of $0.1 \mathrm{M}$ of $\mathrm{HCl}$ were added to $2.5 \mathrm{ml}$ of TEOS under stirring. The obtained solution was kept under stirring at room temperature until a homogeneous clear solution was obtained. The solution was aged at least for 24 hours before used in the coating process. The hydrolyzed TEOS solution was used as a host matrix for the indicators.

\section{Preparation of Indicators}

Indicators solution (0.001 M) of bromothymol blue, prepared using absolute ethanol as solvent.

\section{Stock Solution of Indicators}

The sample solution was prepared by mixing $1 \mathrm{ml}$ of blank hydrolyzed TEOS solution and $1 \mathrm{ml}$ for each indicator.

\section{Preparation of Silica-immobilized Thin Films}

\section{Substrate Cleaning}

Glass were activated by concentrated $\mathrm{H}_{2} \mathrm{SO}_{4}$ for 24 hours, then washed with distilled water and ethanol. The surface was finally rubbed with cleaning paper.

\section{Preparation of Glass/BTB Electrodes using Spin Coating Method}

All thin films layers prepared in this work were made by spinning three drops of the solutions onto a clean glass slide. The coating process was performed using the spin coater machine at $900 \mathrm{rpm}$ spinning speed for $1 \mathrm{~min}$. period time. To obtain multilayers of thin films a subsequent spin coating method was performed after gradually drying of the previous layer at room temperature for 24 hours, then dried at $80^{\circ} \mathrm{C}$ for another 48 hours. And repeat the spin coating two or three time. Where the conducting substrate is usually conducting glass, consisting of glass coated with a thin layer of F-doped $\mathrm{SnO}_{2}$

\section{Sensor Design of Potentiometric Cell}

The potential of the indicator electrode relative to that of the reference electrode was measured on a digital multimeter model YDM 302C (China). Potentials were measured to $\pm 5 \mathrm{mv}$. The potential of Bromothymol blue, Thymol blue, sensor indicators electrodes was measured vs. a saturated calomel electrode (SCE). The error in the measurement of the potential due to liquidjunction potentials in these electrolytes is estimated to be about $0.001 \mathrm{~V}$.

The solution in a beaker is stirred by means of a magnetic stirrer. The electrodes (indicator and reference) were dipped slowly into aqueous solution (acid or reductant). After the steady state potential was attained, the titration of the acid was carried out by addition of $1 \mathrm{ml}$ of the base to the acidic solution, waiting until the steady potential is established and then measured. The potential variation depends on the type of the base, the progress of neutralization process and on the initial concentration of the acid to be titrated. The results were reproducible to satisfactory value of $\pm 5 \mathrm{mV}$ for potential measurements. The process of addition of the titrant was repeated until the equivalence point was reached.

\section{Result and discussion}

\section{The E-pH relation of BTB electrode}

Figure 2 show the change of the open circuit potential (E) of the glass/ Bromo thymol blue (G/ BTB) indicator electrodes with $\mathrm{PH}$. The relation between potential and $\mathrm{pH}(\mathrm{E}-\mathrm{pH})$ plot of the $\mathrm{G} /$ BTB indicator electrode fits straight line with slope of $52.66 \mathrm{mV}$ and $53.11 \mathrm{mV}$ at $298 \mathrm{~K}$. This value is close to the magnitude of the term 2.303 RT/F (where: R gas constant, T absolute temperature and F Faraday constant) at the corresponding temperature (59.1 $\mathrm{mV}$ at $288 \mathrm{~K}$ ). From Figure 2 the E0 value of the sensor electrode, i.e. the potential at $\left[\mathrm{H}^{+}\right]=1$, is computed as $279.1 \mathrm{mV}$ relative to the saturated calomel electrode and can determination by:

$$
\mathrm{HI} n \leftrightarrow \mathrm{H}^{+}+\mathrm{In}^{-}
$$

$$
\begin{gathered}
\mathrm{E}_{\text {ВТв }}=\mathrm{E}_{\mathrm{BTB}}^{o}+\frac{2.303 R T}{F} \log \frac{\left[\mathrm{H}^{+}\right]\left[\mathrm{In}^{-}\right]}{[\mathrm{H} I n]} \\
\mathrm{E}_{\mathrm{BT \textrm {B }}}=\mathrm{E}_{\mathrm{BT \textrm {B }}}^{o}+\frac{2.303 R T}{F} \log \frac{\left[\mathrm{In}^{-}\right]}{[\mathrm{H} I n]}+\frac{2.303 R T}{F} \log \left[\mathrm{H}^{+}\right]
\end{gathered}
$$


Because HIn weak acid

$$
\begin{gathered}
{\left[\mathrm{I} n^{-}\right] \approx[\mathrm{HI} n]} \\
\log \frac{\left[\mathrm{I} n^{-}\right]}{[\mathrm{HI} n]}=0 \\
\mathrm{E}_{\mathrm{BTB}}=\mathrm{E}_{\mathrm{BTB}}^{o}+0.059 \log \left[\mathrm{H}^{+}\right]
\end{gathered}
$$

$$
\mathrm{E}_{\mathrm{BTB}}=\mathrm{E}_{\mathrm{BTB}}^{o}-0.059 p \mathrm{H}
$$

This equation is applicable for the reversible behavior of working electrode. From the developed Nernst equation, we indicate that working electrodes can be used as pH-indicator. At high or low $\mathrm{pH}$, the electrode indicates $\mathrm{pH}$ less than true value as $\mathrm{pH}$ glass electrode, it may be due to damage in electrode or existence of alkali metal ions in solution too.

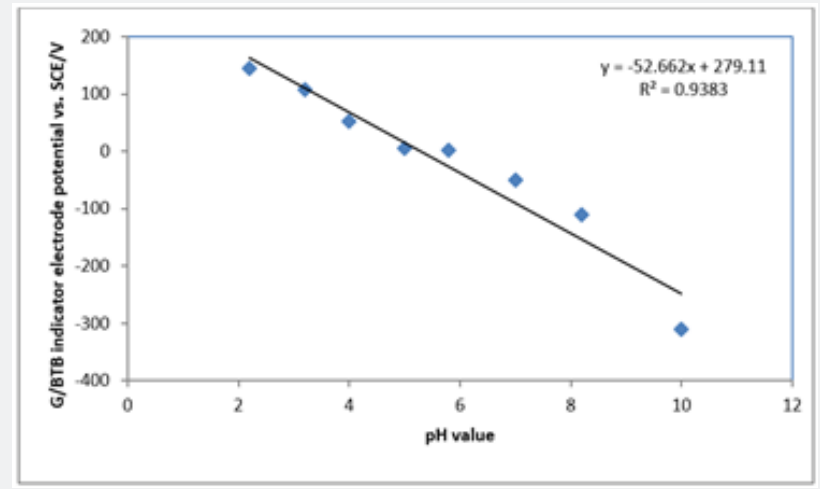

Figure 2: E-PH relation for G/BTB indicator electrode.

\section{Potentiometric Acid-Base Titration}

\section{Effect of Concentration of Acid on Potentiometric Titration}

Figures 3a,b,c represent the relation between the volume of $0.1 \mathrm{M} \mathrm{NaOH}$ with potential shift in the titrations of different concentrations of acetic acids, phosphoric acid and hydrochloric acid for G/BTB electrodes, where the relation between the volume of $0.1 \mathrm{M} \mathrm{HCl}$ with titrations of different concentrations of ammonia represent in figure $3 \mathrm{~d}$. The variation of G/BTB electrode potential at $288 \mathrm{~K}$ with the different volumes of standard $\mathrm{NaOH}$ and $\mathrm{HCl}$ followed typical potentiometric titration curves. These curves show slight decrease in potential (to more negative values) with the addition of the titrant.

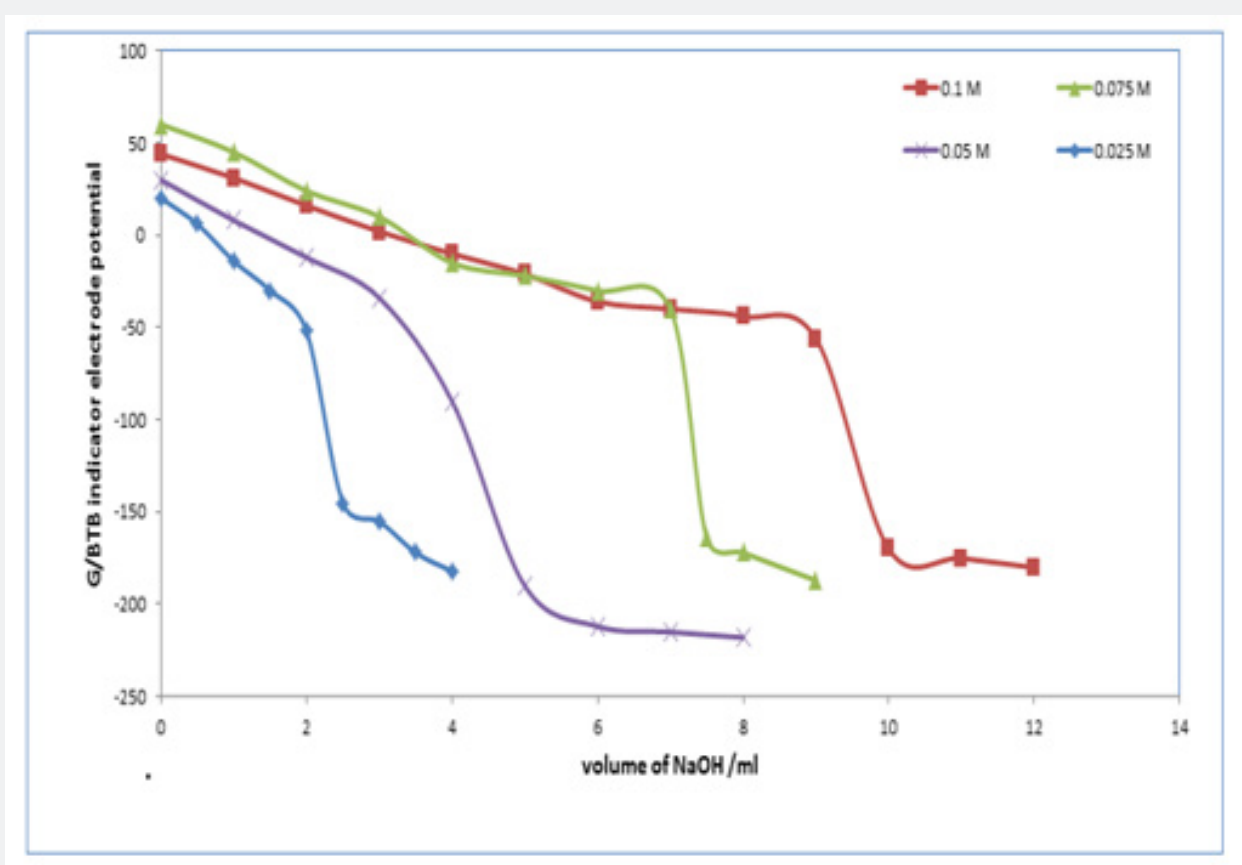

Figure 3a: E-PH relation for G/BTB indicator electrode. 


\section{Organic and Medicinal Chemistry International Journal}

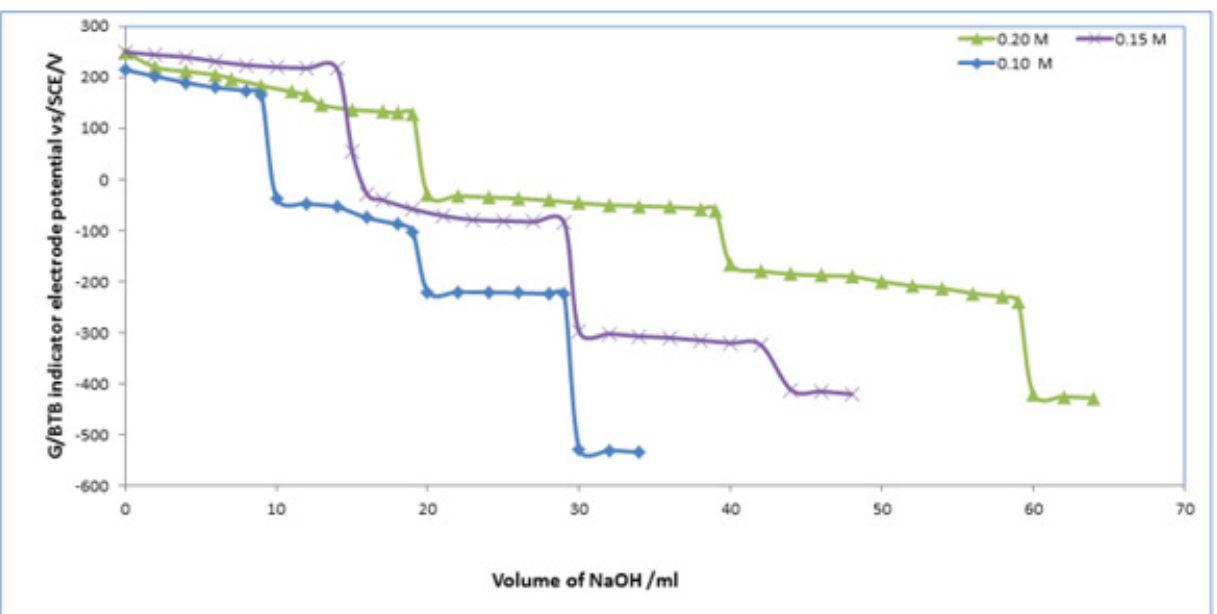

Figure 3b: The effect of concentration of phosphoric acid on potentiometric titration against $0.1 \mathrm{M}$ standard $\mathrm{NaOH}$ for G/BTB electrode at $298 \mathrm{k}$.

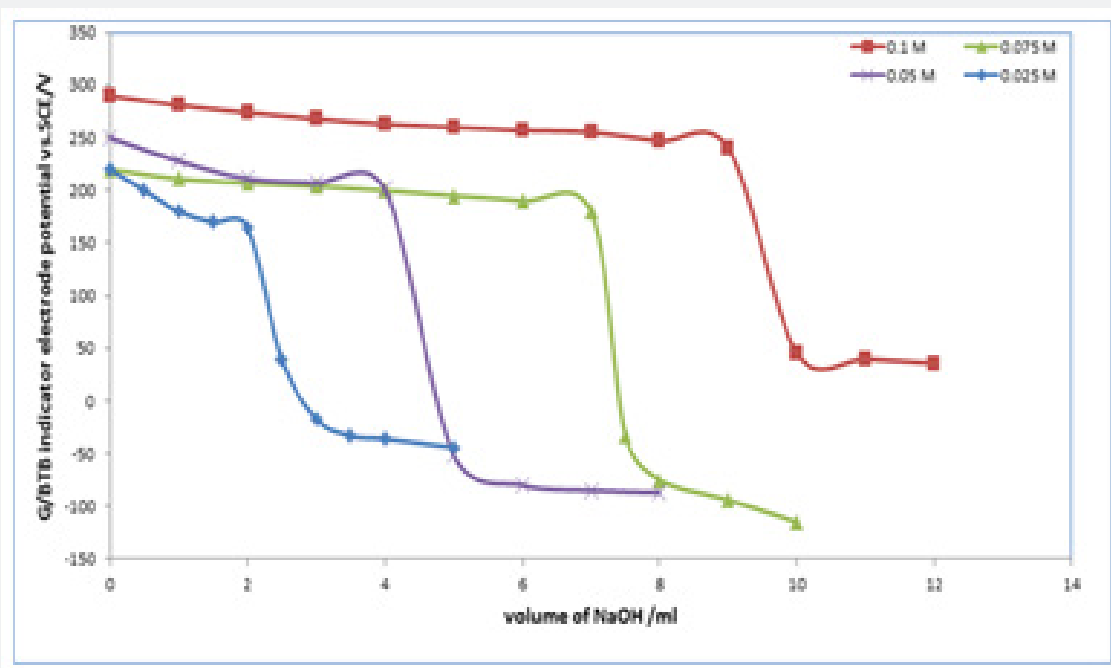

Figure 3c: The effect of concentration of Hydrochloric acid on potentiometric titration against standard $0.1 \mathrm{M} N a \mathrm{OH}$ for G/BTB electrode at $298 \mathrm{k}$.

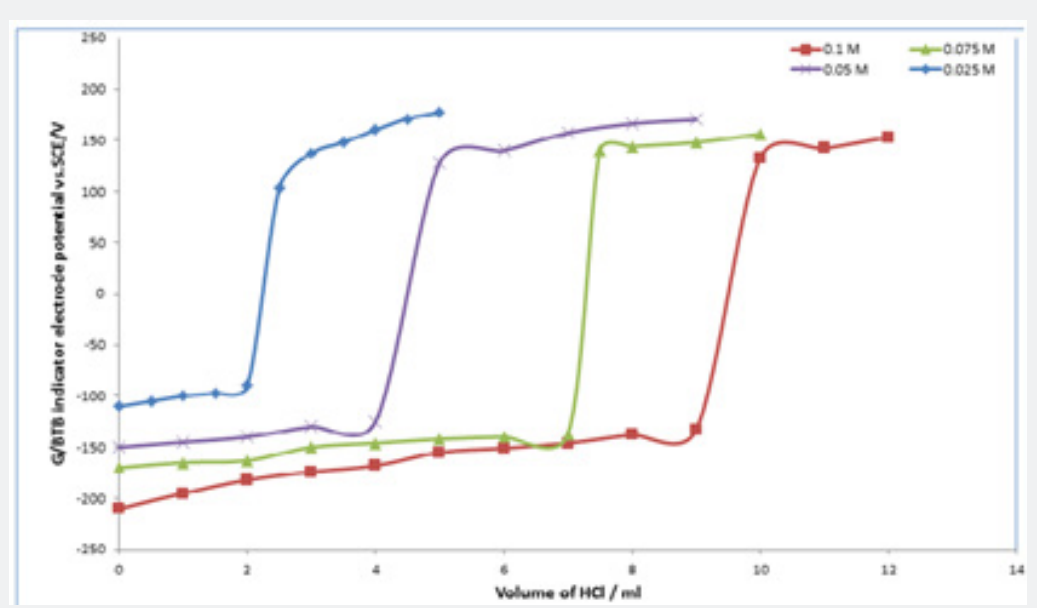

Figure 3d: The effect of different concentration of Ammonia on potentiometric titration against $0.1 \mathrm{M} \mathrm{HCl}$ for G/BTB electrode at $288 \mathrm{~K}$.

How to cite this article: Nasser M Abu Ghalwa*, Fawzi kodih, Nader B Farhat and Rewaa J Abu Saelik. Synthesis of a Novel Sensor Electrode Based on Bromothymol Blue as an Indicator Electrode in Potentiometric Acid-Base Titration in Aqueous Solution. Organic \& Medicinal Chem IJ. $2020 ; 9(3): 555764$. DOI: 10.19080/OMCIJ.2020.09.555764. 


\section{Location of Endpoints}

The locating endpoints shown in Figure 4. Figure 4 represents $\Delta \mathrm{E} / \Delta \mathrm{V}$ against $\mathrm{V}$ for the potentiometric titrations of hydrochloric acid, Acetic acid and phosphoric acid, against $0.1 \mathrm{M} \mathrm{NaOH}$ where the ammonia against $0.1 \mathrm{HCl}$. From the plots the values of endpoints are determined. The molar amounts $\mathrm{A}$ of $\mathrm{CH}_{3} \mathrm{COOH}$ acid, $\mathrm{HCl}$ acid, $\mathrm{CH}_{3} \mathrm{COOH}$ acid, experimental and theoretical amounts of standard $\mathrm{NaOH}, \mathrm{B}_{\mathrm{e}}, \mathrm{B}_{\mathrm{t}}$ and recovery percentage (R\%) for acid-base titrations using BTB indicator electrode are listed in Table 1.

Table 1: The molar amounts $\mathrm{A}$ of $\mathrm{CH}_{3} \mathrm{COOH}$ acid, $\mathrm{HCl}$ acid, $\mathrm{NH}_{4}$ acid, experimental and theoretical amounts of standard $\mathrm{NaOH}, \mathrm{B}_{\mathrm{e}}, \mathrm{B}_{\mathrm{t}}$ and recovery percentage $(R \%)$ for acid-base titrations using BTB indicator electrode.

\begin{tabular}{|c|c|c|c|c|c|c|c|c|c|}
\hline Hydrochloric acid & \multicolumn{3}{|c|}{ Ammonia } & \multicolumn{3}{c|}{ Acetic Acid } & \multicolumn{3}{c|}{ Acid } \\
\hline $\mathrm{R} \%$ & $\mathrm{~B}_{\mathrm{t}}(\mathrm{M}) \mathrm{NaOH}$ & $\mathrm{B}_{\mathrm{e}}(\mathrm{M}) \mathrm{NaOH}$ & $\mathrm{R} \%$ & $\mathrm{~B}_{\mathrm{t}}(\mathrm{M}) \mathrm{NaOH}$ & $\mathrm{B}_{\mathrm{e}}(\mathrm{M}) \mathrm{NaOH}$ & $\mathrm{R}_{0}$ & $\mathrm{~B}_{\mathrm{t}}(\mathrm{M}) \mathrm{NaOH}$ & $\mathrm{B}_{\mathrm{e}}(\mathrm{M}) \mathrm{NaOH}$ & $\mathrm{A}_{(\mathrm{M})}$ \\
\hline 92 & 0.1 & 0.092 & 90 & 0.1 & 0.09 & 95 & 0.1 & 0.095 & 0.1 \\
\hline 92 & 0.075 & 0.069 & 89.3 & 0.075 & 0.067 & 94.6 & 0.075 & 0.071 & 0.075 \\
\hline 92 & 0.05 & 0.05 & 90 & 0.05 & 0.045 & 94 & 0.05 & 0.047 & 0.05 \\
\hline 92 & 0.025 & 0.023 & 90 & 0.025 & 0.022 & 92 & 0.025 & 23 & 0.025 \\
\hline
\end{tabular}

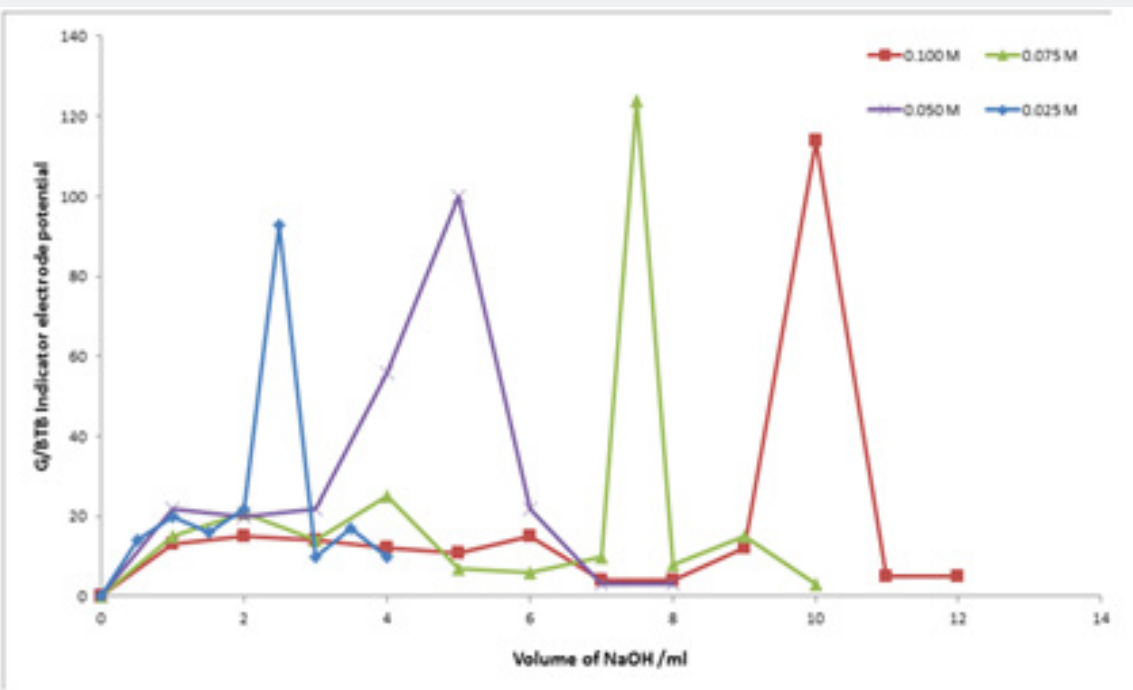

Figure 4a: Locating the endpoints for potentiometric titration of acetic acid with $0.1 \mathrm{M} \mathrm{NaOH}$ at $298 \mathrm{k}$.

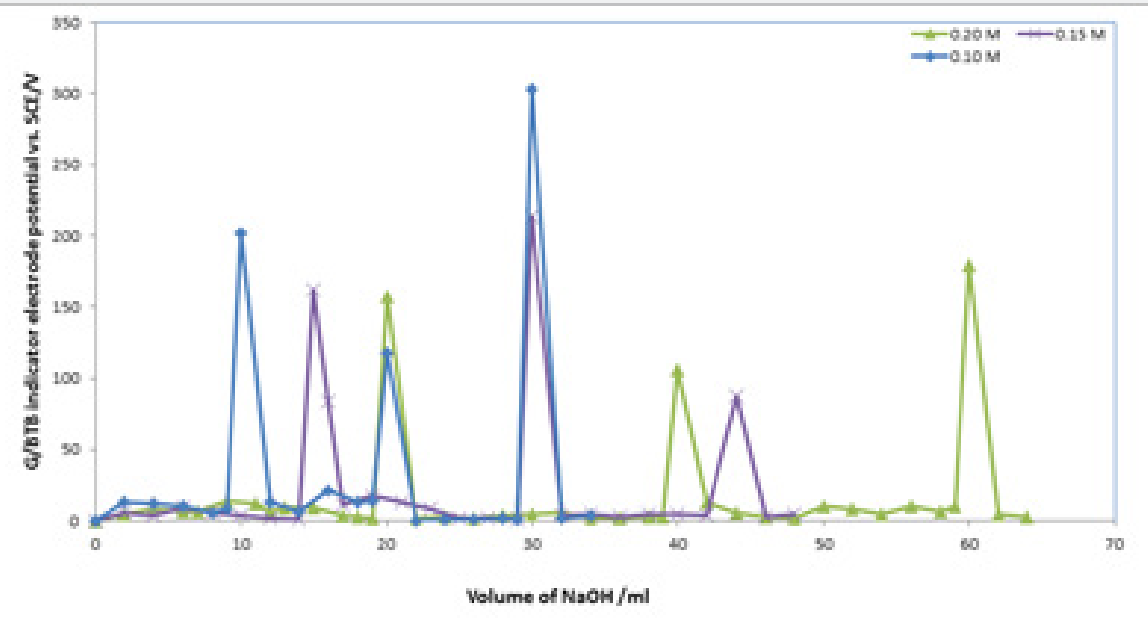

Figure 4b: Locating the endpoints for potentiometric titration of phosphoric acid with $0.1 \mathrm{M} \mathrm{NaOH}$ at $298 \mathrm{k}$. 


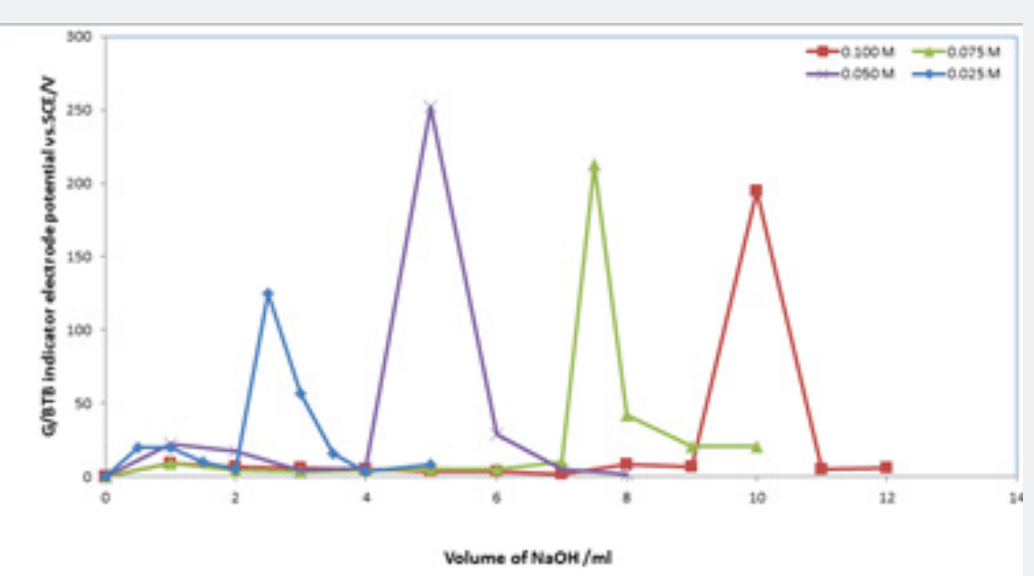

Figure 4c: Locating the endpoints for potentiometric titration of hydrochloric acid with $0.1 \mathrm{M} \mathrm{NaOH}$ at $298 \mathrm{k}$.

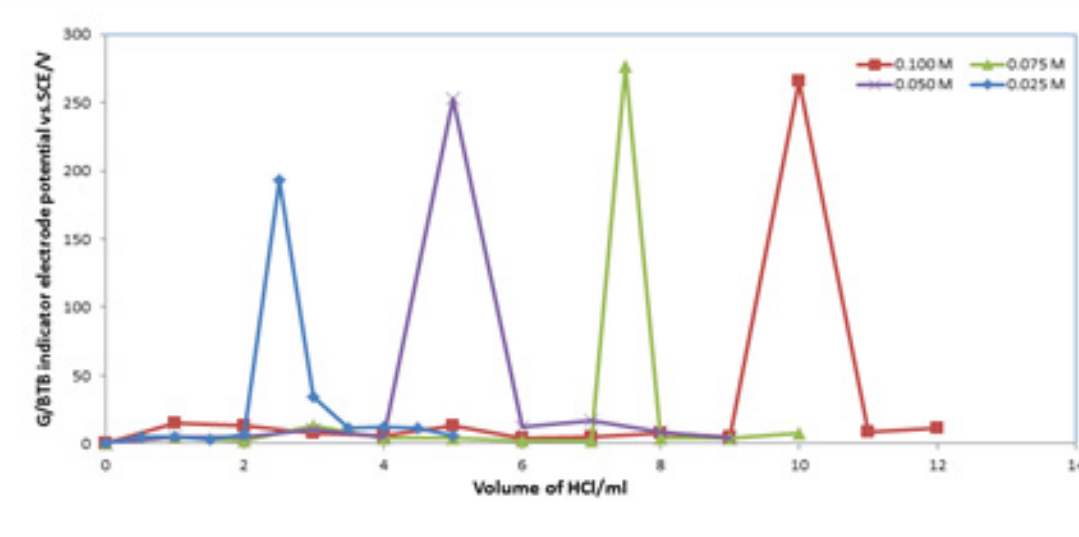

Figure 4d: Locating the endpoints for potentiometric titration of ammonia with $0.1 \mathrm{M}$ at with $0.1 \mathrm{M} \mathrm{HCl}$ at $298 \mathrm{k}$.

Where table 2 represent the molar amounts of Phosphoric $\quad B_{t}$ and recovery percentage (R\%) for acid-base titrations using acid experimental and theoretical amounts of standard $\mathrm{NaOH}, \mathrm{B}_{\mathrm{e}}, \quad$ BTB indicator electrode.

Table 2: The molar amounts of Phosphoric acid experimental and theoretical amounts of standard $\mathrm{NaOH}, \mathrm{B}_{\mathrm{e}}, \mathrm{B}_{\mathrm{t}}$ and recovery percentage $(\mathrm{R} \%)$ for acid-base titrations using BTB indicator electrode.

\begin{tabular}{|c|c|c|c|c|c|c|c|c|c|}
\hline \multirow{3}{*}{$\begin{array}{l}\text { Acid } \\
A(M) \\
\end{array}$} & \multicolumn{9}{|c|}{ Phosphoric acid } \\
\hline & \multicolumn{3}{|c|}{ First step } & \multicolumn{3}{|c|}{ Second step } & \multicolumn{3}{|c|}{ Third step } \\
\hline & $\mathrm{B}_{\mathrm{e}}(\mathrm{M}) \mathrm{NaOH}$ & $\mathrm{B}_{\mathrm{t}}(\mathrm{M}) \mathrm{NaOH}$ & $\mathrm{R} \%$ & $\mathrm{~B}_{\mathrm{e}}(\mathrm{M}) \mathrm{NaOH}$ & $\mathrm{B}_{\mathrm{t}}(\mathrm{M}) \mathrm{NaOH}$ & $\mathrm{R} \%$ & $\mathrm{~B}_{e}(\mathrm{M}) \mathrm{NaOH}$ & $\mathrm{B}_{\mathrm{t}}(\mathrm{M}) \mathrm{NaOH}$ & $\mathrm{R} \%$ \\
\hline 0.1 & 0.09 & 0.1 & 90 & 0.18 & 0.2 & 90 & 0.27 & 0.3 & 90 \\
\hline 0.15 & 0.135 & 0.15 & 90 & 0.27 & 0.3 & 90 & 0.45 & 0.45 & 88 \\
\hline 0.2 & 0.18 & 0.2 & 90 & 0.36 & 0.4 & 90 & 0.45 & 0.6 & 90 \\
\hline
\end{tabular}

The values of the recovery percentage, $\mathrm{R} \%$, for all above titrations are calculated from equation (8). From the plots the values of endpoints and the values of the recovery percentage, $\mathrm{R} \%$, are determined as

$$
R \%=\frac{B_{e}}{B_{t}}(100)
$$

where Be is the experimental amount of base and but is the theoretical amount of base calculated from the stoichiometric equations of neutralization reactions. It is clear from these data that the working electrode can be used as indicator electrode with the satisfactory percentage recovery not less than $88 \%$ in potentiometric titrations. These differences in the recovery percentage may be attributed to the impurities in the reagents. The values of $\mathrm{pK}_{\mathrm{a}}$ (acid equilibrium constant) and $\mathrm{pK}_{\mathrm{b}}$ (base equilibrium constant) for different acids can be determined using the method of half neutralization [16]. They are close to the previously reported values listed in Table 3 for the tested acids. 


\section{Organic and Medicinal Chemistry International Journal}

Table 3: The molar amounts $\mathrm{A}$ of $\mathrm{CH}_{3} \mathrm{COOH}, \mathrm{H}_{3} \mathrm{PO}_{4}$ and ammonia experimental $\mathrm{pK}_{\mathrm{a}}$ and $\mathrm{pK}_{\mathrm{b}}$ for acid-base titrations using BTB indicator electrode.

\begin{tabular}{|c|c|c|c|c|c|c|}
\hline \multirow{3}{*}{$\begin{array}{l}\text { Acid } \\
\text { A(M) }\end{array}$} & \multirow{3}{*}{$\begin{array}{c}\text { Acetic Acid } \\
\mathrm{pK}_{\mathrm{a}}\end{array}$} & \multirow{3}{*}{$\begin{array}{c}\text { Ammonia } \\
\mathbf{p K}_{\mathrm{b}}\end{array}$} & \multicolumn{4}{|c|}{ Phosphoric Acid } \\
\hline & & & \multirow[t]{2}{*}{$A(M)$} & First step & Second step & Third step \\
\hline & & & & $\mathrm{pK}_{\mathrm{a} 1}$ & $\mathbf{p K}_{\mathrm{a} 2}$ & $\mathbf{p K}_{\mathrm{a} 3}$ \\
\hline 0.01 & 4.718 & 4.694 & 0.1 & 2.165 & 7.155 & 2.165 \\
\hline 0.075 & 4.718 & 4.691 & 0.15 & 2.165 & 7.155 & 2.18 \\
\hline 0.05 & 4.718 & 4.694 & 0.2 & 2.165 & 7.155 & 2.165 \\
\hline 0.025 & 4.718 & 4.694 & & & & \\
\hline
\end{tabular}

\section{The Response Time of the Sensor}

It is well known that the response time of the sensor is one of the most important factors in its evaluation and is defined as the time between the addition of analyte to the solution and the time when a limiting potential has been reached $[17,18]$. Figure 5 show the response time of the G/BTB sensor at different concentration of phosphoric acid, acetic acid, Hydrochloric acid, ammonia and $\mathrm{NaOH}$ respectively. Response time, in the range of (100-450) seconds was achieved, which rendered the sensor highly practical.

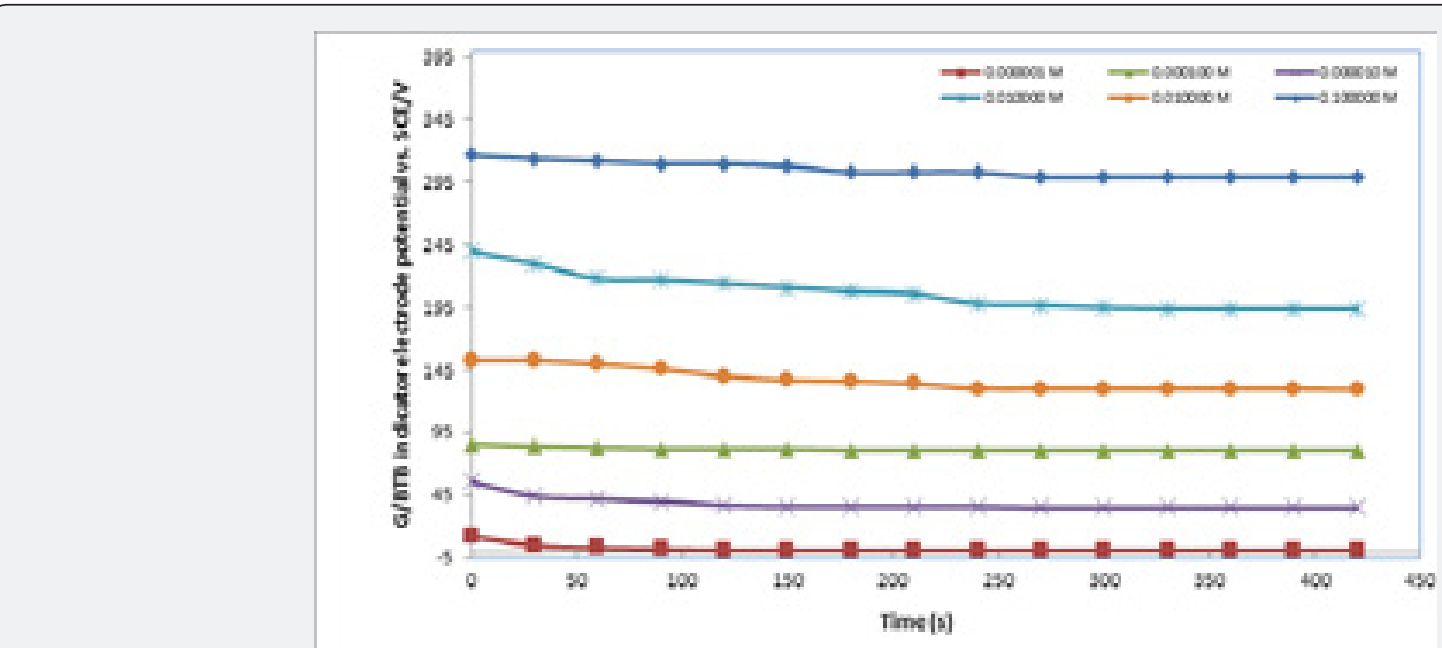

Figure 5a: Response time of G/BTB indicator electrode at different concentration of acetic acid.

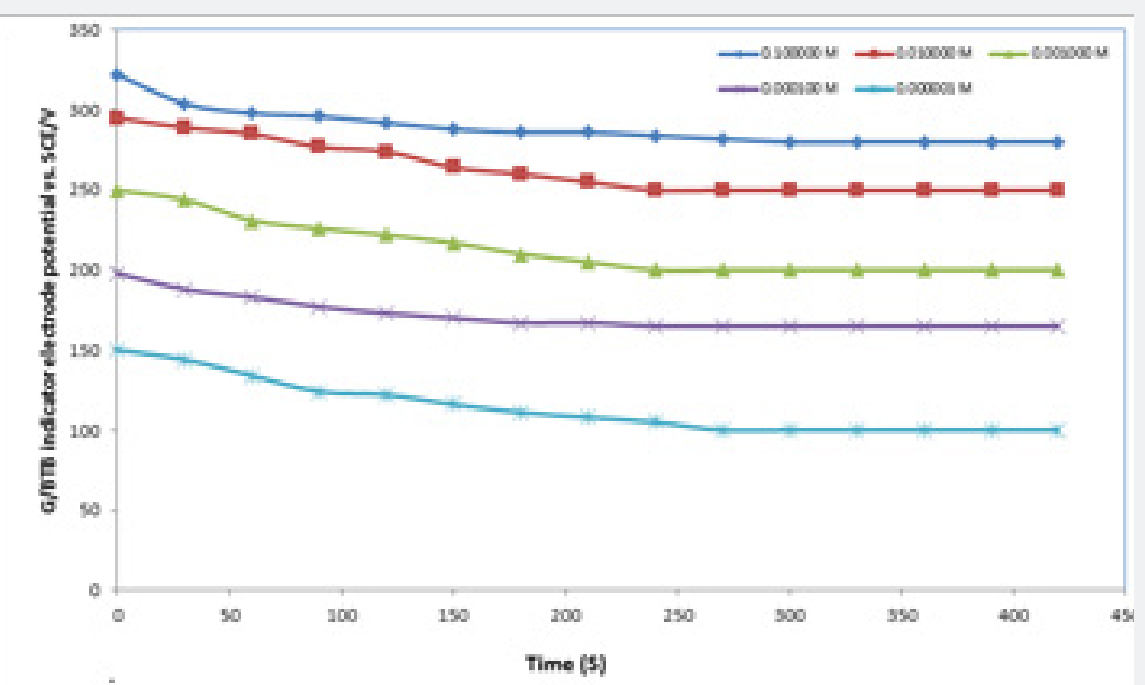

Figure 5b: Response time of G/BTB indicator electrode at different concentration of phosphoric acid. 
Organic and Medicinal Chemistry International Journal

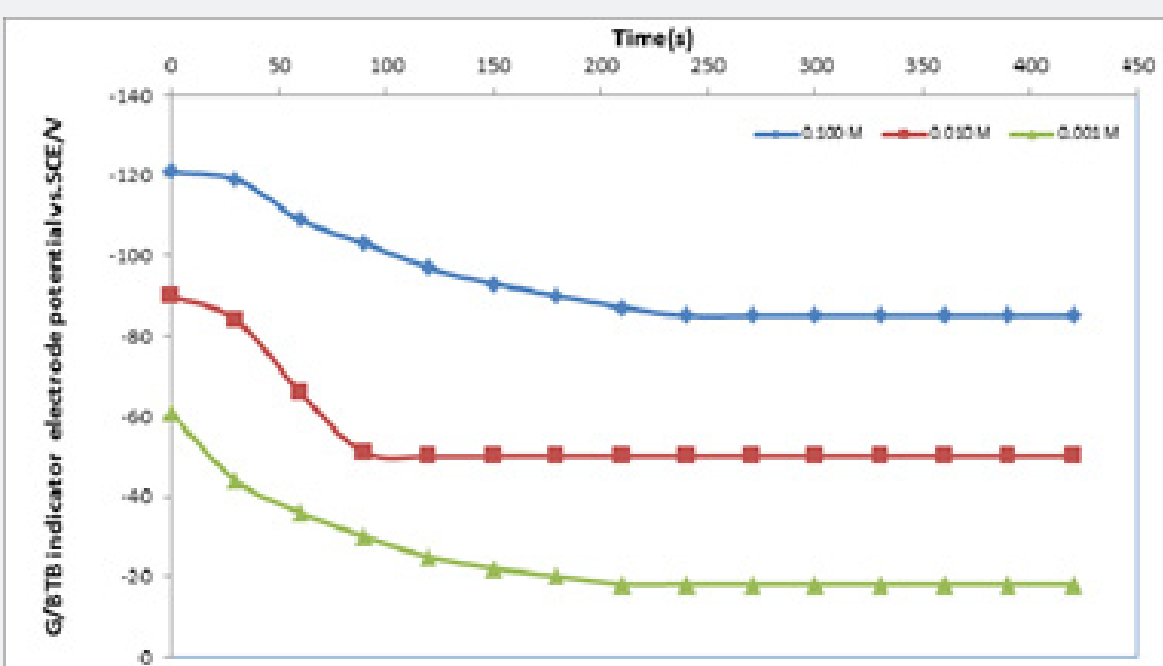

Figure 5c: Response time of G/BTB indicator electrode at different concentration of hydrochloric acid.

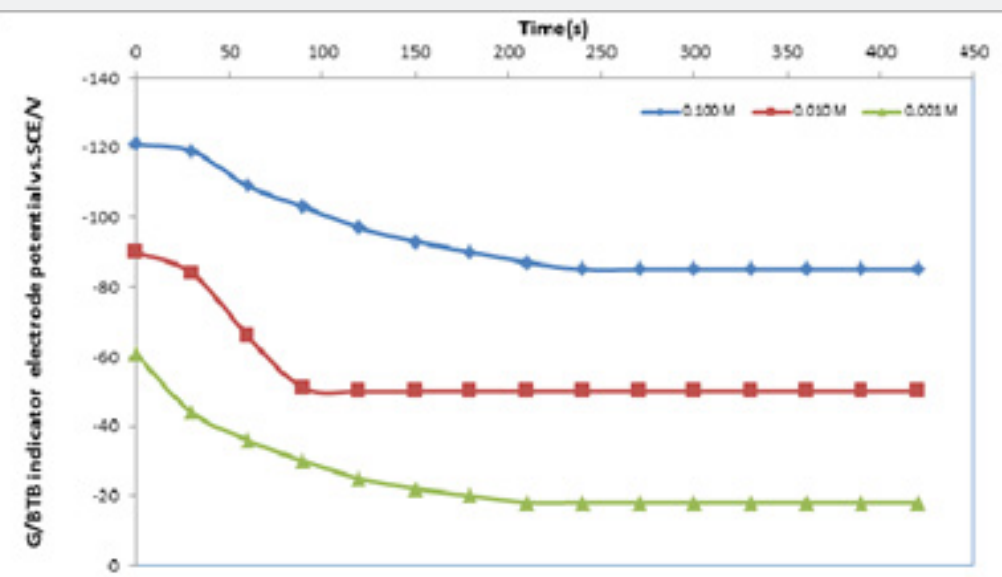

Figure 5d: Response time of G/BTB indicator electrode at different concentration of ammonia.

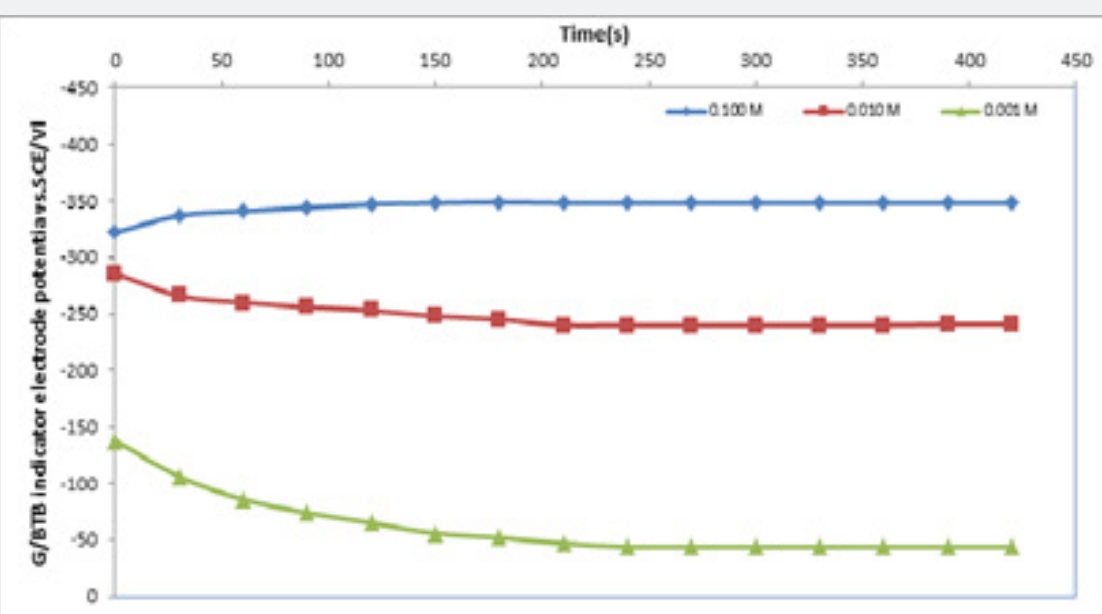

Figure 5f: Response time of G/BTB indicator electrode at different concentration of sodium hydroxide.

How to cite this article: Nasser M Abu Ghalwa*, Fawzi kodih Nader B Farhat and Rewaa J Abu Saelik. Synthesis of a Novel Sensor Electrode Based on Bromothymol Blue as an Indicator Electrode in Potentiometric Acid-Base Titration in Aqueous Solution. Organic \& Medicinal Chem IJ. $2020 ; 9$ (3): 555764. DOI: 10.19080/OMCIJ.2020.09.555764. 


\section{Effect of Temperature on the Response Characteristics}

The $\mathrm{pH}$ of the electrolyte solution depends on the degree of dissociation of the acids and bases present, which is temperature dependent. And this effects on the behavior of the sensor [19]. To study the thermal stability of the sensor, calibration graphs were constructed at different test solution temperatures 15, 25, 35 and $45^{\circ} \mathrm{C}$. According to Figure 6. The sensor would be used for $\mathrm{pH}$ measurements in the range from (2-11). At lower temperatures, like $283 \mathrm{~K}$, the slope of the sensor was about $34.12 \mathrm{mV} /$ decade. However, when the temperature of the test solutions was adjusted to $298 \mathrm{~K}$, the slope significantly increased to $52.66 \mathrm{mV} /$ decade. By raising the temperature to $308 \mathrm{~K}$ and $318 \mathrm{~K}$ the slope increased to $64.64 \mathrm{mV} /$ decade and $66.54 \mathrm{mV} /$ decade respectively.

Figure 6 shows the square of the correlation coefficient $\left(r^{2}\right)$ for $\mathrm{pH}$ measurements using the sensor, at different temperatures, as compared to $\mathrm{pH}$ values obtained by a conventional $\mathrm{pH}$ electrode (Hanna Instruments HI 1131 pH combination electrode) was found to change as the temperature increases where as $\mathrm{r} 2$ values for measurements at $283 \mathrm{~K}, 298 \mathrm{~K}, 308 \mathrm{~K}$, and $318 \mathrm{~K}$ were 0.9655 , $0.9383,0.9482,0.9876$, respectively. This indicates that better results could be obtained at $298 \mathrm{~K}$. Where figure 7 represent the Correlation between the conventional glass electrode ( $\mathrm{pH}$ meter) and G/BTB indicator electrode.

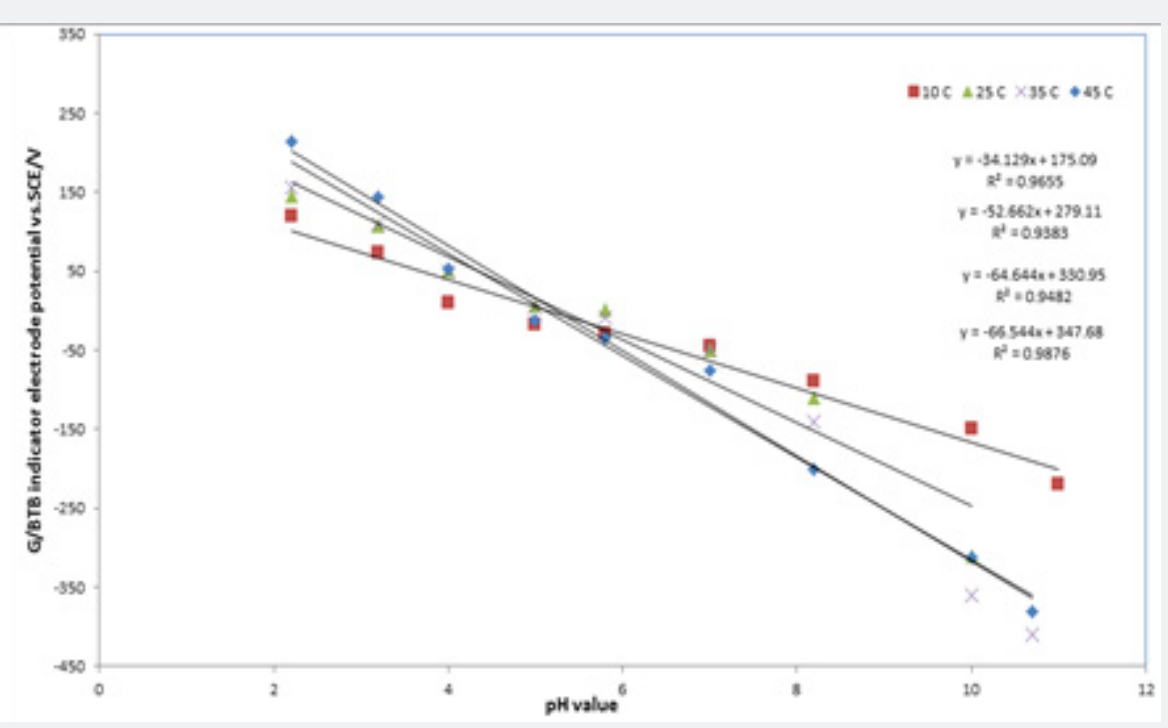

Figure 6: Effect of temperature for $\mathrm{pH}$ measurements using the G/BTB indicator electrode.

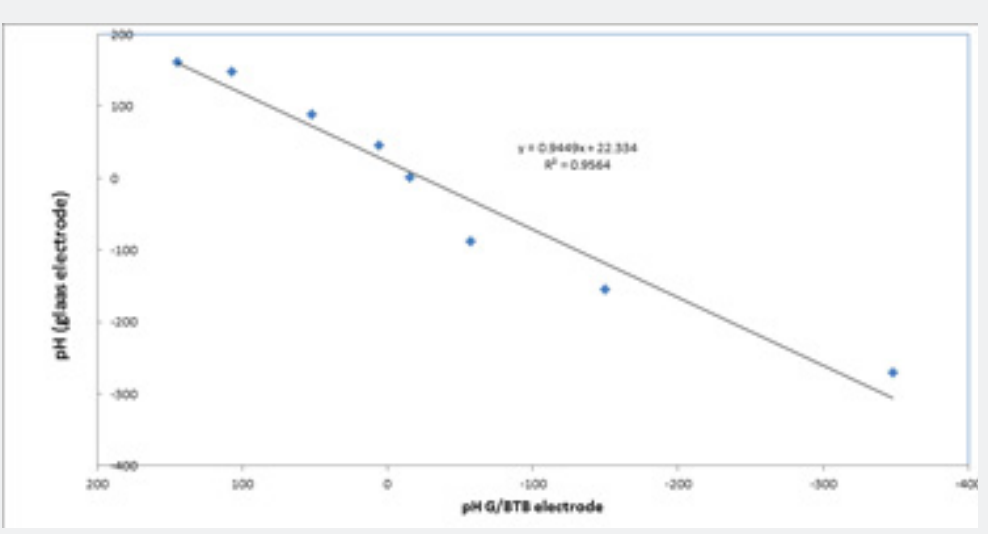

Figure 7: Effect of temperature for $\mathrm{pH}$ measurements using the G/BTB indicator electrode.

\section{Conclusion}

a. In the present study the trials were made for the preparation of the modified electrodes of type glass/ Bromothymol blue G/BTB and their use as sensor indicator electrodes in the potentiometric acid-base titrations in aqueous solution at $298 \mathrm{~K}$ b. The recovery percentage for potentiometric acidbase titration using G/BTB as indicator electrode was calculated.

c. The E-pH curve is linear with slope of $0.052 \mathrm{~V} /$ decade for the G/BTB electrode at $298 \mathrm{~K}$. This value is close to the theoretical value $2.303 \mathrm{RT} / \mathrm{F}(0.059 \mathrm{~V}$ at $298 \mathrm{~K})$. 
d. The standard potential of the tested electrode, E0, is computed as $279.11 \mathrm{mV}$ with respect to SCE as reference electrode. Acetic acid, phosphoric acid, hydrochloric acid and ammonia were successfully potentiometric titration with $\mathrm{NaOH}$ as titrant in aqueous medium at $298 \mathrm{~K}$.

e. In this study applied the different temperature like $283 \mathrm{~K}$, $298 \mathrm{~K}, 308 \mathrm{~K}$, and $318 \mathrm{~K}$ were the correlation coefficient $\left(r^{2}\right) 0.9655,0.9383,0.9482,0.9876$, respectively.

\section{References}

1. Schwarz J, Trommer K, Gerlach F, Michael M (2018) All-Solid-State Screen-Printed Sensors for Potentiometric Calcium (II) Determinations in Environmental Samples. American Journal of Analytical Chemistry 9(3): 113-123.

2. Skoog DA, West FJ, Crouch ST (2013) Fundamentals of Analytical Chemistry ( $9^{\text {th }}$ Edn): Cengage Learning Boston.

3. Jakubowska M, Bas B, Kubiak WW (2009) End-point detection in potentiometric titration by continuous wavelet transform. Talanta 79: 1398-1405.

4. Van Hulle SWH, De Meyer S, Vermeiren TJL, Vergote A, Hogie J, et al. (2009) Practical application and statistical analysis of titrimetric monitoring of water and sludge samples. Water SA 35(3): 329-333.

5. Ghalwa NA (2012) Development of a Novel Solid-State Sensor Electrode Based on Titanium Thin Film as an Indicator Electrode in Potentiometric and Conductometric Acid-Base Titration in Aqueous Solution. Journal of Sensors.

6. Afkhami A, Shirzadmehr A, Madrakiana T, Bagheri H (2014) Improvement in the performance of a $\mathrm{Pb} 2+$ selective potentiometric sensor using modified core/shell SiO2/Fe304 nanostructure. Journal of Molecular Liquids 199: 108-114.

7. Pradeep DJ, Dave K (2013) A Novel Inexpensive and Less Hazardous Acid-Base Indicator. Journal of Laboratory Chemical Education 1(2): 34-38.

8. Jennings P A, Mullen CA, Roy M (2010) Titration and pH Measurement University of California San Diego, California, USA P 1-6.
9. Vasilyeva MS, Rudnev VS, Arefieva OD, Lapina AS (2016) $\mathrm{Ti} / \mathrm{TiO}_{2}$ indicator electrodes formed by plasma electrolytic oxidation for potentiometric analysis. International Journal of Environmental Analytical Chemistry 96: 1128-1144.

10. Jokić A B, Džudović R M (2013) The application of hydrogenpalladium electrode for potentiometric acid-base determinations in tetrahydrofuran. J Serb Chem Soc 78 (8): 1203-1212.

11. Mihajlović Lj, Nikolić-Mandić S, Vukanović B (2009) Use of the sulfide minerals pyrite and chalcopyrite as electrochemical sensors in nonaqueous solutions. The potentiometric titration of weak acids in alcohols. Anal Sci 25: 437.

12. Mihajlović R P, Stanić ZD (2005) Natural monocrystalline chalcopyrite and galena as electrochemical sensors in non-aqueous solvents. Part I: Potentiometric titrations of weak acids in $\gamma$-butyrolactone and propylene carbonate. J Solid State Electrochem 9: 558.

13. Balamurugan A, Chen ZW, Chen SM (2008) Electrochemical Preparation of Bromo Thymol Blue-PEDOT Composite Electrode and Characterization. Journal of The Electrochemical Society 155: 151-156.

14. Stani Z, Girousi S (2011) Carbon paste electrode in potentiometry: the state of the art and application in modern electroanalysis (a review). Sensing in Electroanalysis 9: 89-128.

15. Issa MN, Shehata MZ, Fawzi SK, Fatma HA (2014) Sol-gel encapsulation of bromothymol blue $\mathrm{pH}$ indicatorin presence of Gemini 12-2-12 surfactan. J Sol-Gel Sci Technol 71: 16-23.

16. Illingworth JA (1981) A common source of error in $\mathrm{pH}$ measurements. Biochemical Journal 195: 259-262.

17. Buck RP, Lindner E (1994) Recommendations for nomenclature of ion selective electrodes (IUPAC Recommendations). Pure and Applied Chemistry 66(12): 2527-2536.

18. Buck PR, Lindner E (1994) IUPAC Recommendation for Nomenclature of Ion-Selective Electrodes. Pure and Applied Chemistry 66(12): 25272536.

19. Buck RP, Cosofret VV (1993) Recommended procedures for calibration of ion-selective electrodes. Pure Appl Chem 65(8): 1849-1858.

\section{Your next submission with Juniper Publishers will reach you the below assets}

- Quality Editorial service

- Swift Peer Review

- Reprints availability

- E-prints Service

- Manuscript Podcast for convenient understanding

- Global attainment for your research

- Manuscript accessibility in different formats

( Pdf, E-pub, Full Text, Audio)

- Unceasing customer service

Track the below URL for one-step submission

https://juniperpublishers.com/online-submission.php 